\title{
The Effects of Slow Stroke Back Massage and Lavender Aromatherapy on Blood Pressure in Hypertensive Patients
}

\author{
Fakhrudin Nasrul Sani, Mellia Silvy Irdianty
}

School of Health Sciences Kusuma Husada, Surakarta

\section{ABSTRACT}

Background: Elderly is an age group which is extremely susceptible to suffer from health problems such as hypertension. Hypertension among the elderly is instigated by structural and functional changes in blood vessels. The changes include atherosclerosis, loss of connective tissue elasticity, and decreased vascular muscle relaxation that it reduces the distension and tensile strength of blood vessels. One of the therapies that may be implemented to elderly with hypertension is slow stroke back massage (SSBM) and lavender aromatherapy. The study aims to discover the effects of slow back massage (SSBM) and lavender aromatherapy toward the reduced blood pressure among hypertensive elderly.

Subjects and Method: It was a quasi-experiment study with no control group which had been conducted in Posyandu (Integrated Health Post) Kamboja, Plesungan, Gondangerjo, Karanganyar, Central Java, in July 2019. A sample of 40 elderlies was selected by using total sampling. The dependent variables were systolic and diastolic blood pressure. The independent variables were slow stroke back massage (SSBM) and lavender aromatherapy. Blood pressure was measured by sphygmomanometer. The data were analyzed by using Wilcoxon.

Results: The average systolic blood pressure post slow stroke back massage therapy and lavender aroma therapy was (Mean=133.63; $\mathrm{SD}=7.34$ ) compared with prior therapy was (Mean $=167.80$; $\mathrm{SD}=6.12$ ) with the value of $\mathrm{p}<0.001$. The average diastolic blood pressure post slow stroke back massage therapy and lavender aroma therapy was (Mean $=68.28 ; \mathrm{SD}=4.25)$ compared with the prior therapy was $(\mathrm{Mean}=68.88 ; \mathrm{SD}=5.72)$ with the value of $\mathrm{p}<0.001$.

Conclusion: Slow stroke back massage (SSBM) lavender aromatherapy may lower down blood pressure of hypertensive elderly.

Keywords: Hypertension, slow stroke back massage, Lavender aromatherapy, elderly

\section{Correspondence:}

Fakhrudin Nasrul Sani. School of Health Sciences Kusuma Husada, Surakarta. Email: fakhrudin_ns@ymail.com.

Cite this as:

Sani FN, Irdianty MS (2020). The Effects of Slow Stroke Back Massage and Lavender Aromatherapy on Blood Pressure in Hypertensive Patients. J Matern Child Health. 05(03): 178-184. https://doi.org/10.26911/theijmed.2020.05.03.01.

(ㄷ) (1) Indonesian Journal of Medicine is licensed under a Creative Commons

Attribution-Non Commercial-Share Alike 4.0 International License.

\section{BACKGROUND}

Hypertension or also known as high blood pressure, is one of the diseases that is marked by the elevated blood pressure. Hypertension is specified as increased systolic blood pressure $\geq 140 \mathrm{mmHg}$ diastolic blood pressure $\geq 90 \mathrm{mmHg}$ in two different measurements (Indonesian Ministry of Health, 2014). The symptoms of the disease are headache, blush ing, aching nape, bad temper, tinnitus (buzzing in the ears), insomnia, shortness of breath, dizzy eyes, stiff nape, fatigue, epistaxis (Damayati, 2013).

Hypertension among elderly is caused by structural and functional changes in blood vessel. The changes include atherosclerosis, loss of connective tissue elasticity, and decreased vascular muscle relaxation that it 
reduces the distention and tensile strength of blood vessels (Jalalodini et al., 2016; Rafiei et al., 2018). Uncontrolled high blood pressure will lead to stroke, myocardial infarct, kidney failure, encephalopathy, convulsion (Corwin, 2013).

One of the therapies applied to hypertensive elderly is massage (Harris and Richard, 2010). One of the non-pharmaceutical methods of reducing stress is massage therapy. It is a traditional method of treatment which is currently considered as part of the health care system (Noto et al., 2010; Benavente and Costa, 2011). Massage therapy has beneficial physiological effects such as dilation of blood vessels, increased skin temperature and body relaxation, the production of lactic acid in the muscles, improvement of lymphatic and venous circulation, and stimulation and healing of the connective tissue. Massage therapy promotes psychosocial wellbeing and reduces stress. Massage therapy is commonly used to relieve pain and anxiety (Noto et al., 2010; Nazari et al., 2015).

Slow stroke back massage (SSBM) is a back massage with rhythmical slow stroke by using hands which consists of 60 strokes per minute given for 3 up to 10 minutes period (Mook and Woo, 2014).

The autonomic nervous system is responsible for maintaining homeostasis against external conditions by controlling the activities of the viscera, blood vessels, and secretory glands. As the incidences of certain diseases such as diabetes, affecting the vascular system, are increasing, the awareness of their effects on the autonomic nervous system has been heightened (Lee et al., 2011).

Recent findings suggest that this mechanism involves a parasympathetic nervous system response elicited by the stimulation of pressure receptors within the skin. For example, in healthy adults, massage therapy promotes relaxation and reduces stress. The effects of massage therapy on various psycholo- gical and neuroendocrine factors may be mediated by the stimulation of dermal and/or sub-dermal pressure receptors that are innervated by vagal afferent fibers, which ultimately project to structures involved in ANS regulation (Diego and Field, 2009).

Parasympathetic nervous system releases acetylcholine neurotransmitter by reducing cardiac muscle contractility, stroke volume, arterial vasodilation, and vein afterward reducing blood pressure (Muttaqin, 2013). Aromatherapy is a therapy which uses essential oil and pure oil essence to help restoring and maintaining health, boosting mood, freshening and revivifying body and soul (Hutasoit, 2012).

The therapy can be performed by using several methods such as massage, spray, inhalation, bathing, gargling, compress, and also air freshener. Several forms of aromatherapy namely incense, candle, and essential oil. Incense is made out of sweet smelling roots which are crushed into incense powder, whereas aromatherapy candle is made out of essential oil that produces sweet smelling aroma when it is burnt. Essential oil itself uses furnace with candle underneath to heat it up or by using electric furnace (Ali et al., 2015).

Slow stroke back massage (SSBM) therapy would be combined with lavender aromatherapy. It an easy, simple, and affordable therapy. Slow stroke back massage (SSBM) therapy and lavender aromatherapy is expected to give the more effective result in lowering down blood pressure of hypertensive patients. The study aims to analyze the effect of slow stroke back massage (SSBM) and lavender aromatherapy toward blood pressure of hypertensive elderly.

\section{SUBJECTS AND METHOD}

\section{Study Design}

It was a quasi-experiment study with a pre and posttest with no control group. The study 
Sani et al. / The Effects of Slow Stroke Back Massage and Lavender Aromatherapy

was conducted in integrated health post (posyandu) Kamboja, Plesungan, Gondangerjo, Karanganyar, Central Java, in July 2019.

\section{Population and Sample}

Population of the study was hypertensive elderly. There was a total of 40 elderlies selected by using total sampling.

\section{Study Variables}

Dependent variables were systolic and diastolic blood pressure. Independent variables were slow stroke back massage (SSBM) therapy and lavender aromatherapy.

\section{Operational Definition of Variables} Slow Stroke Back Massage was defined as one of non-pharmacological interventions by slowly giving massage (stroke) at the back. Lavender aromatherapy was a healing treatment by using natural plant extracts (Lavender).

Systolic blood pressure was defined as the top value (in $\mathrm{mmHg}$ ) refers to the amount of pressure in arteries during the contraction of heart muscle. The measurement scale was continuous.

Diastolic blood pressure was defined as the bottom value (in $\mathrm{mmHg}$ ) when the blood forced against artery walls as heart relaxes. The measurement scale was continuous.

\section{Study Instruments}

Systolic and diastolic blood pressure was measured by sphygmomanometer.

\section{Data Analysis}

Bivariate analysis was conducted to describe continuous data (in mean, SD, minimum, and maximum) and categorical (in $\mathrm{n}$ and \%). The difference of systolic and diastolic blood pressure prior and post therapy was analyzed by using Wilcoxon test.

\section{RESULTS}

\section{Univariate analysis}

The elderly's characteristics based on sex and age was described in Table 1. Characteristics of study sample indicate that most of the sample were women of $60-74$ years old.

\section{The result of bivariate analysis}

The average systolic blood pressure post slow stroke back massage therapy and aromatherapy was lower $($ Mean= 133.63; $\mathrm{SD}=7.34)$ compared with prior therapy $($ Mean $=167.80$; $\mathrm{SD}=6.12$ ) with $\mathrm{p}<0.001$.

The average diastolic blood pressure post slow stroke back massage therapy and aromatherapy was lower $($ Mean $=68.28 ; \mathrm{SD}=$ 4.25) compared with prior therapy (Mean= 68.88; $\mathrm{SD}=5.72$ ) with $\mathrm{p}<0.001$.

Table 1. Elderly characteristics based on sex and age

\begin{tabular}{lcc}
\hline Variables & N & \% \\
\hline Sex & & \\
Males & 19 & 47.5 \\
Female & 21 & 52.5 \\
Age & & \\
$45-59$ years & 19 & 47.5 \\
$60-74$ years & 21 & 52.5 \\
\hline
\end{tabular}

Table 2. Characteristics of systolic and diastolic blood pressure (mmHg)

\begin{tabular}{lccc}
\hline Blood pressure & Mean & Min. & Max. \\
\hline Prior & & & 180 \\
Systolic & 167.80 & 157 & 95 \\
Diastolic & 85.28 & 78 & \\
Post & & & 145 \\
Systolic & 133.63 & 120 & 80 \\
Diastolic & 68.88 & 60 & \\
\hline
\end{tabular}


Sani et al. / The Effects of Slow Stroke Back Massage and Lavender Aromatherapy

Table 3. The difference of elderly's systolic and diastolic blood pressure prior and post slow stroke back massage (SSBM) therapy and lavender aromatherapy

\begin{tabular}{lccc}
\hline Blood Pressure & Mean & SD & p \\
\hline Systolic & & & $<0.001$ \\
Pre & 167.80 & 6.12 & \\
Post & 133.63 & 7.34 & $<0.001$ \\
Diastolic & & & \\
Pre & 85.28 & 4.25 & 5.72 \\
Post & 68.88 & & \\
\hline
\end{tabular}

\section{DISCUSSION}

The result of the study indicated that the majority of the sample was female and aged 6074 years old. According to Singalingging (2011), in average women will experience the increased risk of hypertension or high blood pressure after menopause at the age above 45 years.

Harison et al. (2012), conveys that women who do not yet experience menopause are protected by estrogen which contributes in increasing the level of high density lipoprotein (HDL). The high level of HDL cholesterol is a factor in preventing the occurence of atheroclerosis. The effect of estrogen protection is considered as the explanation toward the existence of women imunity during premenopause age. Premenopause women starts losing estrogen little by little which all this time protects blood vessel from damage.

The reason for gender difference in blood pressure levels is multifactorial and incompletely understood. There are several hypotheses including the potential role of sex hormones, the renin-angiotensin system (RAS), oxidative stress, endothelia, weight gain and sympathetic activation (Nuzzo et al. 2010; Reckelhoff, 2001).

Premenopausal hypertensive women with regular menstrual cycles appear to have lower plasma estradiol levels than agematched normotensive women, and the protective function of oestrogen has been suggested to account for the 10- to 15-year delay in presentation of CVD in women compared with men (Oparil, 2003; Gudmundsdottir et al., 2012).

The condition related to age is the by product of arteriosclerosis wornout of the main arteries particularly the aorta, and as the result of reduced elasticity. The hardened arteries causes arteries getting stiffened, the arteries and aorta loss their flexibility. The older the person, the risk of hypertension is getting bigger, that the prevalence among elderly is relatively high which is around $40 \%$ with mortality is around 50\% at the age above 60 years. Arteries loss their elasticity and blood pressure is increasing with the age (Wang and Bennett, 2012; Head et al., 2017).

Several studies indicate that the combination of regular massage therapy and aromatherapy implementation may reduce the level of stress hormone cortisol, increase the response activities of relaxation, and muscle relaxation, sedative and euphoria (Jalalodini et al., 2016; Rafiei et al., 2018).

According to American Massage Therapy Association, massage is one of the approaches that can be used to relieve muscle pain or as the means of relaxation. Slow stroke back massage (SSBM) intervention toward clients with terminal diseases is proven can decrease systolic and diastolic blood pressure (Potter and Perry, 2012).

Relaxation therapy is one of the techniques to reduce stress and muscle tension. Relaxation therapy is required for hypertensive patients to make blood vessel relaxed hence vasodilation will occur which lead to 
Sani et al. / The Effects of Slow Stroke Back Massage and Lavender Aromatherapy

normal blood pressure (Jalalodini et al., 2016; Rafiei et al., 2018).

Slow stroke back massage (SSBM) is a back massage with rhythmical slow stroke by using hands (Mook and Woo, 2014). Stimulation by pressing and massaging the back part with correct techniques and procedures can affect toward body physiology changes. According to a study by Cinar and Eser (2012) the implementation of before bed $10 \mathrm{mi}-$ nutes massage for three days is proven can increase sleeping quality of the elderly because of the relaxation effect of massage.

The implementation of slow stroke back massage (SSBM) with lavender aromatherapy can produce muscle relaxatio by tactile stimuli of body tissue that instigates complex neuro humoral inside hypothalamic-pituitary axis (HPA) to sircuit through nervous system pathway. Stress adaptation is regulated by HPA capacity to secrete hormones such as cortisol and endorphin that reduce the activities of sympathetic nerves and increase the response of parasympathetic. The administration of lavender aromatherapy simultaneously placed on the burner works by stimulating olfactory nerve cells and influencing the work of limbic by increasing the sense of positive and relaxed (Remington, 2012).

Essential oil which is absorbed by body by inhaling aromatherapy will bring the aromatics into the nose, cilia which is inside the nose functions as receptor that delivers electrochemical message to central nerves system. The message will activate the emotional center, subsequently memory will carry it back to the entire body through blood circulation. The message carried to the entire body will be converted into a sense of joy and relaxed that it affects blood vessel dilation which will instigate decreased blood pressure (Jumarani, 2011). It makes heart works without demanding strong tension to pump and blood circulation throughout the body will be maximum (Remington, 2012).

\section{AUTHOR CONTRIBUTION}

Fakhrudin Nasrul Sani and Mellia Silvy Irdianty measured systolic and diastolic blood pressure prior and post intervention, performed slow stroke back massage therapy, administrated Lavender aromatherapy, collected data, analyzed the data and prepared the manuscript.

\section{CONFLICT OF INTEREST}

There was no conflict of interest.

FUNDING AND SPONSORSHIP

There was no external funding.

\section{ACKNOWLEDGEMENT}

We give our gratitude to the elderly in Posyandu (integrated health post) Kamboja, Plesungan, Gondangrejo, Karanganyar, Central Java who had willingly participated in the study.

\section{REFERENCE}

Ali B, Al-Wabel NA, Shams S, Ahamad A, Khan SA, Anwar F (2015). Essential oils used in aromatherapy: A systemic review. Asian Pac J Trop Biomed. 5(8): 601-611. https://doi.org/10.101-6/j.apjtb.2015.05.007.

Benavente SBT, Costa ALS (2011). Physio-logical and emotional responses to stress in nursing students: an integrative review of scientific literature. Acta paul. enferm. 24(4): 571-576. http://doi.org/10.1590/So103-21-002011000400019.

Cinar S, Eser I (2012). Effect on sleep qua-lity of back massage in older adults in rest home. Deuhyo ED, 5(1): 2-7. https://pdfs.semanticscholar.org/4a-8b/e6ec43d89c016a71f3068a74e2c5ea54 69e7.pdf

Corwin, Elizabeth J (2013). Buku saku patofisiologi(Pathophysiology pocket book). Jakarta: Buku Kedokteran EGC. 
Sani et al. / The Effects of Slow Stroke Back Massage and Lavender Aromatherapy

Damayati D (2013). Sembuh total diabetes, asam urat, hipertensi tanpa obat (Total cure of diabetes, gout, hypertension without drugs). Yogyakarta: Pinang Merah Publisher.

Diego MA, Field T (2009). Moderate pressure massage elicits a parasympathetic nervous system response. Int J Neurosci. 119(5): 630-638. https://doi.org/10.1080/00207450802329605.

Gudmundsdottir H, Høieggen A, Stenehjem A, Waldum B, Ingrid Os (2012). Hypertension in women: latest findings and clinical implications. Ther Adv Chronic Dis. 3(3): 137-146. https://doi.org/10.1177/2040622312438935

Harris M, Richards KC (2010). The physiologogical and psychological effects of slow stroke back masase and hand masase on relaxation in older people. $\mathrm{J}$ Clin Nurs. 19(7-8): 917-926. https:-//doi.org/10.1111/j.1365-2702.2009.-03165.X

Head T, Daunert S, Goldschmidt-Clermont PJ (2017). The aging risk and atherosclerosis: A fresh look at arterial homeostasis. Front Genet. 8:216. doi: 10.3389/fgene.2017.00216.

Hutasoit (2012). Aromaterapi. Jakarta: Pustaka Populer Obor.

Indonesian Ministry of Health (2013). Basic Health Research. Jakarta.

Indonesian Ministry of Health. (2014). Hipertensi. Jakarta: Kementerian Kesehatan RI.

Jalalodini A, Nourian M, Saatchi K, Kavousi A, Ghaljeh M (2016). The effective-ness of slow-stroke back massage on hospitalization anxiety and physio-logical parameters in school-age children: A randomized clinical trial study. Iran Red Crescent Med J. 18(11): e36567. https:// doi.org/10.5812/ircmj.36567

Free PMC Article Jumarani L (2011). The essence of Indonesia spa: Spa Indonesia gaya Jawa dan Bali. Jakarta: PT Gramedia Pustaka Utama.

Lee YH, Park BNR, Kim SH (2011). The effects of heat and massage application on autonomic nervous system. Yonsei Med J. 52(6): 982-989. https://doi.org/10.3349\%2Fymj.2011.52.6.982

Muttaqin A (2013). Buku ajar asuhan keperawatan klien dengan gangguan sistem. (Nursing care book for clients with system disorders) Jakarta: Salemba Medika.

Mook E, Woo CP (2014). The effects of slowstroke back masase on anxiety and shoulder pain in elderly stroke patients. Complement Ther Nurs Midwifery. 10(4): 209-206. https://doi.org/10.1016/j.ctnm.2004.05.006

Nandhini S (2014). Essential hypertention a review artikel. J Pharm Sci Res. 6(9): 305-307. https://www.jpsr.ph-armainfo.in/Documents/Volumes/Vol6Issueo 9/jpsro6091404.pdf

Nazari F, Mirzamohamadi M, Yousefi H (2015). The effect of massage therapy on occupational stress of Intensive Care Unit nurses. Iran J Nurs Mid wi-fery Res. 20(4): 508-515. https://doi.org/10.4103\%2F1735-9066.161001.

Noto Y, Kudo M, Hirota K (2010). Back massage therapy promotes psychological relaxation and an increase in Salivary chromogranin A release. J Anesth. 24(6): 955-8. https://doi.org/10.1007/s00540-010-1001-7

Nuzzo A, Rossi R, Modena MG (2010). Hypertension alone or related to the metabolic syndrome in postmenopausal women. Expert Rev Cardiovasc Ther. 8(11): 1541-8. https://doi.org/10.1586/erc.10.147

Oparil S, Zaman MA, Calhoun DA (2003). Pathogenesis of hypertension. Ann Intern Med. (9): 761-76. https://doi.- 
Sani et al. / The Effects of Slow Stroke Back Massage and Lavender Aromatherapy

org/10.7326/ooo3-4819-139-9-2003$11040-00011$.

Potter PA, Perry AG (2012). Buku ajar fundamental keperawatan: Konsep, proses, \& praktik. Edisi 4 Vol 2. Jakarta: Gramedia PustakaUtama.

Reckelhoff JF (2001). Gender differences in the regulation of blood pressure. Hypertension. 37(5): 1199-208. https://doi.org/10.1161/01.hyp.37.5.1199

Remington R (2012). Calming music and hand massage with agitated elderly. Nursing Research. 51(5): 317-323. Https://doi.org/10.1097/o0006199-200209000-00008
Rafiei F, Ameri F, Haghani H, Ghobadi A (2018). Effect of aromatherapy massage with lavender and chamomile oil on the intensity of background pain in burn patients. Iran J Nurs. 31(114): 2837. http://dx.doi.org/10.29252/ij-n.31.114.28

Wang JC, Bennett M (2012). Aging and Atherosclerosis: Mechanisms, functional consequences, and potential therapeutics for cellular senescence. Circulation Res. 111(2): 245-259. https://doi.org/10.1161/CIRCRESAHA.111.261388 